\title{
A Disorder of Tryptophan Metabolism in Chronic Granulomatous Disease
}

\author{
A. F. HEELEY,^ MARY E. HEELEY, JENNIFER HARDY, $\dagger$ and J. F. SOOTHILL \\ From the Departments of Biochemistry and Immunology of the Institute of Child Health, and \\ The Hospital for Sick Children, Great Ormond Street, London
}

\begin{abstract}
Heeley, A. F., Heeley, M. E., Hardy, J., and Soothill, J. F. (1970.) Archives of Disease in Childhood, 45, 485. A disorder of tryptophan metabolism in chronic granulomatous disease. 5 children with chronic granulomatous disease had a disorder of tryptophan metabolism, resulting in excretion of gross excess of hydroxykynurenine, kynurenine, and xanthurenic acid, with or without tryptophan loading. Hydroxykynurenine predominated, and in this and other ways the findings were different from those present in most defects of tryptophan metabolism, but were similar to those in pyridoxine deficiency. Oral pyridoxine $30 \mathrm{mg}$./day corrected this defect, but had no effect on the nitroblue tetrazolium reaction, or bacterial killing by polymorphonuclear leucocytes.
\end{abstract}

During routine biochemical investigations on a child with chronic granulomatous disease a 24-hour urine specimen was found to contain large amounts of several UV fluorescent substances, the predominant one of which was characterized by two-dimensional paper chromatography as 3hydroxykynurenine (HKy), a metabolite of tryptophan. Large amounts of xanthurenic acid (XA) and kynurenic acid $(\mathrm{KyA})$, and kynurenine $(\mathrm{Ky})$ were also found.

Abnormal tryptophan metabolism occurs in several diseases, but tryptophan loading is usually required to show it, and diseases accompanied by a high sponteneous excretion of metabolites are uncommon (Musajo and Benassi, 1964). Moreover, of the latter, only one has been reported where HKy is excreted in excess of any other metabolite (Komrower et al., 1964). An investigation into the quantitative aspects of tryptophan metabolism in children with chronic granulomatous disease was, therefore, undertaken.

\section{Materials and Methods}

The patients, boys aged from 2 to 8 years, were diagnosed by the typical clinical syndrome (Berendes, Bridges, and Good, 1957), by qualitative (Windhorst,

\footnotetext{
Received 2 January 1970.

^Present address: The Ida Darwin Hospital, Fulbourn, Cambridge.

†Present address: Royal Victoria Infirmary, Queen Victoria Road, Newcastle upon Tyne 1.
}

Holmes, and Good, 1967) and quantitative nitro blue tetrazolium reaction (NBT) (Baehner and Nathan, 1968), and by a quantitative test of bactericidal activity (Chandra, Cope, and Soothill, 1970) derived from the method of Quie et al. (1967). All were grossly abnormal by all these parameters. Most of them have been described by Thompson and Soothill (1970); Case 1 in this study was Case 5 in the previous report, $2=2$, $4=6$, and $5=3$. The series showed a range of severity such that Cases 2 and 5 were relatively severely affected and 3, 4, and 6 relatively mildly. Cases 1 and 4 were brothers. Most of them had had episodes of liver infection.

Five children with recurrent infection, but without evidence of chronic granulomatous disease were also studied. Two boys aged 6 years were among the random hospital patients for whom data on excretion of tryptophan metabolities after tryptophan load have been previously reported (Heeley, 1965), which are reproduced here; infected Control 1 had chronic bronchitis, and Control 2 had chronic cervical adenitis of unknown cause. In addition, we have made two-dimensional paper chromatographic studies without tryptophan loading of urine from 3 children who had chronic infection, mainly respiratory -2 boys with cystic fibrosis, and 1 girl with probable partial specific immunity deficiency.

Urine was stored cool, with merthiolate, during collection, and then frozen at $-15{ }^{\circ} \mathrm{C}$. 24-hour urine collections were used for studies without tryptophan load. After tryptophan load $(0 \cdot 1 \mathrm{~g} . / \mathrm{kg}$. body weight) administered as described previously (Heeley, 1965), the patients were encouraged to micturate frequently, and 
each voiding during the next 24 hours was saved separately for analysis.

$\mathrm{Ky}, \mathrm{HKy}$, and 3-hydroxyanthranilic acid (HAA) were measured in urine by the procedures previously described (Heeley, 1965). Indole-3-acetic acid was determined in acid hydrolysed urine by the method of Weissbach et al. (1959). Tryptophan was measured by plasma and urine by the method of Denckla and Dewey (1967), blood being collected by finger-prick. Some control data, using these techniques, on random hospital subjects have been reported by Heeley (1965) and, using unhydrolysed urine, by Michael et al. (1964).

Two-dimensional paper chromatography of a volume of urine, using as solvents butanol; acetic acid; water $(12: 3: 5 \mathrm{v} / \mathrm{v})$ and $7 \%(\mathrm{w} / \mathrm{v})$ aqueous sodium chloride containing $1 \%(\mathrm{w} / \mathrm{v})$ acetic acid, was performed by the method of Jepson (1969). The chromatogram was examined for UV fluorescent, and Ehrlich reagent reactive substances.

The quantitative NBT test was done by the method of Baehner and Nathan (1968). Bacterial killing was measured by a technique (Chandra et al., 1970) derived from that of Quie et al. (1967), to be described. Staphylococci, surviving in the patient's polymorphs 20 and 140 minutes after in vitro phagocytosis, were measured by nephelometry after 16 hours' culture; results are expressed as O.D. $140 \mathrm{~min}$.

$$
\text { O.D. } 20 \mathrm{~min} \text {. }
$$

\section{Results}

Table I shows the results of excretion of $\mathrm{HKy}$, $\mathrm{Ky}$, and HAA in the series of hospital control boys and girls, aged $6 / 12$ to 12 years, reported by Michael et al. (1964), and 5 patients with chronic granulomatous disease. The excretion of $\mathrm{HKy}$ was raised in Cases 1, 2, 3, and 4; that of $\mathrm{Ky}$ in Cases 1, 2, and 3. There was also a small excess of HAA in Cases 3 and 5. In Cases 1, 2, and 3 considerably more $\mathrm{HKy}$ was excreted than either of the other two substances. No spots in the position of $\mathrm{HKy}, \mathrm{Ky}$, and HAA were noted in the chromatograms of urines of the three children with chronic

TABLE I

Excretion of Tryptophan Metabolites by Children with Chronic Granulomatous Disease

\begin{tabular}{|c|c|c|c|}
\hline & $\mathrm{Ky}$ & HKy & HAA \\
\hline $\begin{array}{l}\text { Hospital controls, mean } \\
\text { SD }\end{array}$ & \multicolumn{3}{|c|}{\begin{tabular}{ccc}
\multicolumn{2}{c}{$(\mu$ mole/kg. body wt. per $24 \mathrm{hr})}$. \\
0.9 & $1 \cdot 10$ & 1.54 \\
\pm 0.13 & \pm 0.22 & \pm 0.54
\end{tabular}} \\
\hline $\begin{array}{l}\text { Case } 1 \\
\text { Case } 2 \text { Mean } \\
\text { Range } \\
\text { Case } 3 \\
\text { Case } 4 \\
\text { Case } 5\end{array}$ & $\begin{array}{l}2 \cdot 8 \\
5 \cdot 7 \\
4 \cdot 3-8 \cdot 8 \\
5 \cdot 0 \\
1 \cdot 0 \\
0 \cdot 9\end{array}$ & $\begin{array}{l}6 \cdot 1 \\
12 \cdot 6 \\
8 \cdot 1-19 \cdot 8 \\
9 \cdot 2 \\
1 \cdot 9 \\
1 \cdot 4\end{array}$ & $\begin{array}{l}1 \cdot 7 \\
2 \cdot 2 \\
1 \cdot 6-2 \cdot 9 \\
3 \cdot 2 \\
2 \cdot 5 \\
2 \cdot 9\end{array}$ \\
\hline
\end{tabular}

infection, or in the parents of the brothers, Cases 1 and 4 , and the parents of Case 2. As mentioned in the introduction, a gross excess of many spots representing tryptophan metabolites of the kynurenine pathway were detected in the urine of Cases 1, 2, and 3, but not in Cases 4 and 5 .

Cases 1 and 2, with raised excretion of $\mathrm{HKy}$ under normal dietary conditions, and Case 4 who did not show this, were given L-tryptophan loads and the excretion of the amino acid and the three metabolites was determined. The amount of $\mathrm{HKy}, \mathrm{Ky}$, and HAA per kg. body weight in the 8 hours after the tryptophan load are given in Table II, with data from 13 control children of comparable age, reported previously by Heeley (1965). All 3 patients excreted a gross excess of $\mathrm{HKy}$ which was the predominant substance of the three in all cases; $\mathrm{Ky}$ and HAA excretion was also clearly abnormal in Cases 1 and 2, but not in Case 4.

\section{TABLE II}

Excretion of Tryptophan Metabolites by 3 Children with Chronic Granulomatous Disease After Loading with L-tryptophan $(0 \cdot 1 \mathrm{~g} . / \mathrm{kg}$. body wt.)

\begin{tabular}{|c|c|c|c|}
\hline & Ky & HKy & HAA \\
\hline $\begin{array}{l}\text { Case } 1 \\
\text { Case } 2 \\
\text { Case } 4\end{array}$ & $\begin{array}{l}\text { ( } \mu \text { mole/1 } \\
11 \cdot 6 \\
30 \cdot 0 \\
8 \cdot 8\end{array}$ & $\begin{array}{l}\text { g. body wt. } \\
12 \cdot 6 \\
60 \cdot 6 \\
9 \cdot 4\end{array}$ & $\begin{array}{c}\text { per } 8 \mathrm{hr} .) \\
2 \cdot 5 \\
4 \cdot 0 \\
3 \cdot 0\end{array}$ \\
\hline $\begin{array}{l}\text { Infected control } 1 \\
\text { Infected control } 2\end{array}$ & $\begin{array}{l}0 \cdot 9 \\
4 \cdot 0\end{array}$ & $\begin{array}{l}0 \cdot 8 \\
4 \cdot 0\end{array}$ & $\begin{array}{l}1 \cdot 0 \\
2 \cdot 5\end{array}$ \\
\hline $\begin{array}{l}\text { Control* mean }(n=13) \\
\text { Observed range }\end{array}$ & $\begin{array}{l}3 \cdot 7 \\
0 \cdot 9-9 \cdot 7\end{array}$ & $\begin{array}{l}1 \cdot 9 \\
0 \cdot 6-6 \cdot 0\end{array}$ & $\begin{array}{l}2 \cdot 0 \\
0 \cdot 8-3 \cdot 8\end{array}$ \\
\hline
\end{tabular}

$\star^{\star}$ Heeley (1965).

The amount of each substance per $\mathrm{kg}$. body weight, for each voiding of urine, following tryptophan load, is plotted against the time of voiding, for Case 1 , and for a boy of similar age and weight, who was being studied for metabolic abnormality in view of mental abnormality, but in whom no disorder of tryptophan metabolism was found (Fig. 1). A prolonged and raised excretion of $\mathrm{HKy}$ and $\mathrm{Ky}$ was noted in Case 1 , and excretion of HAA was less than that of the control subject.

The plasma levels of tryptophan were measured in Case 1 and in the control child in the fasting state, and 1, 3, and 4 hours after the tryptophan load. Values obtained (Table III) were similar in the two subjects, and comparable with the normal range reported by Yarbro and Anderson (1966).

Cases 1,2 , and 3 were given pyridoxine $\mathrm{HCl}$ (30 mg. t.d.s. orally), and $\mathrm{HKy}, \mathrm{Ky}$, and $\mathrm{HAA}$ were 

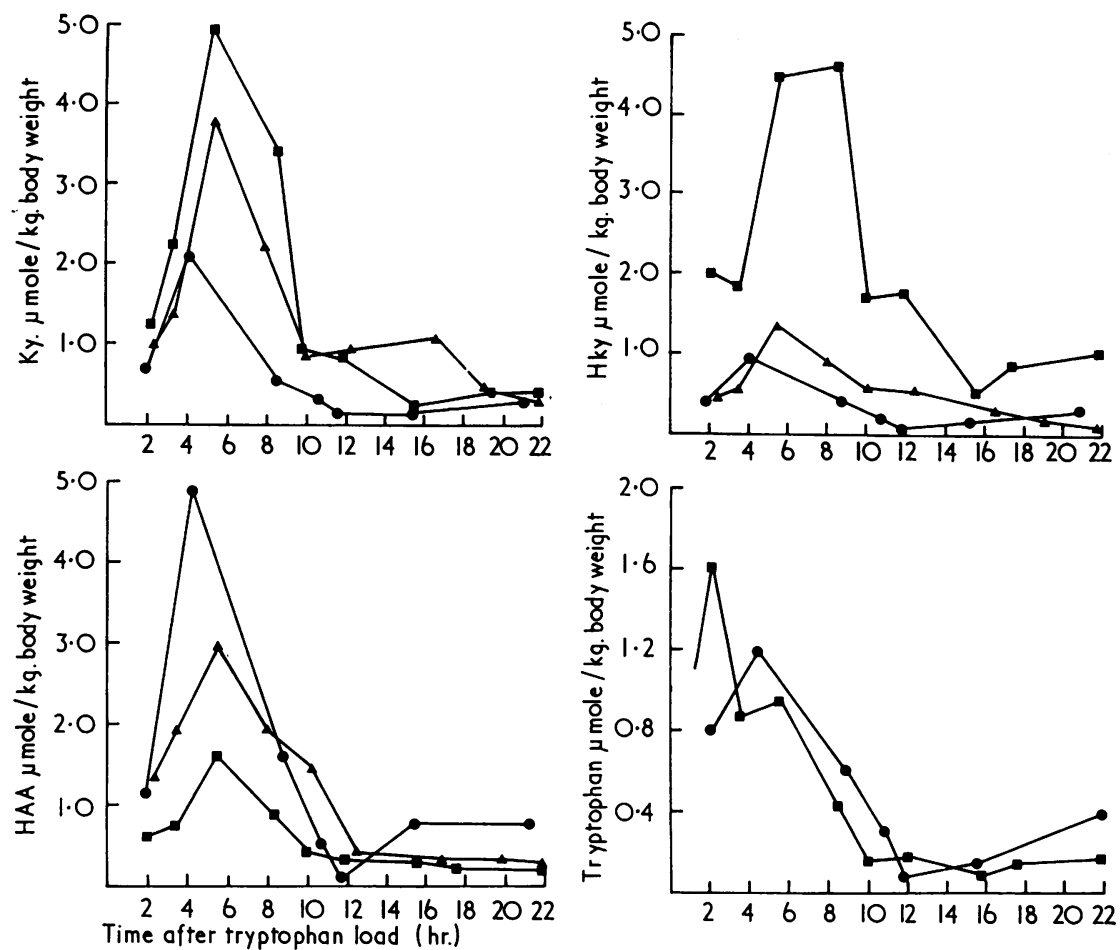

Fig. 1.-Excretion of tryptophan metabolites ( $\mu$ mole/kg. body weight per voiding) after a tryptophan load. - Case 1 with chronic granulomatous disease; on normal diet and no added pyridoxine. $\Delta$ Case 1 on a normal diet plus pyridoxine (30 mg. daily). Control child, on normal diet.

TABLE III

Plasma Tryptophan Levels After an Oral L-tryptophan Load

\begin{tabular}{l|c|c|r|r}
\hline & \multicolumn{3}{|c}{ Plasma Tryptophan (mg./100 ml.) } \\
\cline { 2 - 4 } & Fasting & $1 \mathrm{hr}$. & $3 \mathrm{hr}$. & $4 \mathrm{hr}$. \\
\hline Case 1 & 1.7 & $11 \cdot 4$ & $9 \cdot 2$ & $6 \cdot 2$ \\
$\begin{array}{l}\text { Control child } \\
\text { (as in Fig. 1) }\end{array}$ & 1.9 & 12.0 & $10 \cdot 0$ & $6 \cdot 5$ \\
\hline
\end{tabular}

measured after 3-4 days; a conspicuous fall in $\mathrm{HKy}$ occurred in all three (Table IV). A considerable fall in Ky occurred in Cases 2 and 3, with no consistent change in HAA. Under these conditions a tryptophan load was also metabolized normally (Fig. 1). During the 8 hours after the tryptophan load, while receiving normal dietary amounts of pyridoxine, Case 1 excreted 2.9 moles/ $\mathrm{kg}$. body weight of indole-3-acetic acid (normal range $1 \cdot 0-6 \cdot 8 \mu \mathrm{moles} / \mathrm{kg}$. body weight per 8 hours, with a mean value of $2 \cdot 9$ (Heeley, 1966)).
Values for the NBT test and the bactericidal test showed no change after pyridoxine treatment in Cases 1, 2, 3, and 6, and nicotinamide treatment in Case 3 (Table V).

\section{Discussion}

Three out of five children with chronic granulomatous disease excreted increased amounts of $\mathrm{HKy}$ and, to a lesser extent $\mathrm{Ky}$, under normal dietary conditions. L-tryptophan load produced an even greater excretion of these tryptophan metabolites, again with the predominance of $\mathrm{HKy}$. The plasma tryptophan tolerance curve and the urinary tryptophan excretion following the amino acid load were within normal limits, which suggests that the urinary excretion of metabolites of the 'kynurenine' pathway was not the result of an excessive amount of tryptophan being diverted into that pathway. Our data show that normal amounts of tryptophan were metabolized through the IAA pathway, and, though we did not investigate in detail the 5hydroxyindolyl-3-acetic acid (HIAA) pathway, a 
TABLE IV

Effect of Pyridoxine (30 mg./day) on Excretion of HKy, Ky, and HAA in Chronic Granulomatous Disease

\begin{tabular}{|c|c|c|c|c|c|c|c|c|}
\hline \multirow{2}{*}{$\begin{array}{l}\text { Case } \\
\text { No. }\end{array}$} & \multicolumn{4}{|c|}{ Before Pyridoxine } & \multicolumn{4}{|c|}{ After Pyridoxine $30 \mathrm{mg} \cdot /$ day } \\
\hline & $\begin{array}{c}\text { Days Before } \\
\text { Pyridoxine }\end{array}$ & HKy & Ky & HAA & $\begin{array}{l}\text { Days on } \\
\text { Pyridoxine }\end{array}$ & HKy & Ky & HAA \\
\hline $\begin{array}{l}1 \\
2 \\
3\end{array}$ & $\begin{array}{r}7 \\
1 \\
14\end{array}$ & $\begin{array}{r}6 \cdot 1 \\
19 \cdot 8 \\
9 \cdot 2\end{array}$ & $\begin{array}{l}2 \cdot 8 \\
6 \cdot 2 \\
5 \cdot 0\end{array}$ & $\begin{array}{l}1 \cdot 7 \\
2 \cdot 9 \\
3 \cdot 2\end{array}$ & $\begin{array}{l}3 \\
3 \\
4\end{array}$ & $\begin{array}{l}1 \cdot 3 \\
2 \cdot 5 \\
1 \cdot 2\end{array}$ & $\begin{array}{l}2 \cdot 8 \\
2 \cdot 9 \\
2 \cdot 9\end{array}$ & $\begin{array}{l}1 \cdot 3 \\
4 \cdot 0 \\
1 \cdot 7\end{array}$ \\
\hline
\end{tabular}

TABLE V

Effect of Pyridoxine and Nicotinamide Treatment on NBT and Bactericidal Tests in Chronic Granulomatous Disease

\begin{tabular}{|c|c|c|c|c|c|c|c|c|c|c|}
\hline \multirow[b]{2}{*}{$\begin{array}{l}\text { Case } \\
\text { No. }\end{array}$} & \multicolumn{2}{|c|}{ Before Pyridoxine } & \multicolumn{4}{|c|}{ After Pyridoxine } & \multicolumn{4}{|c|}{ After Nicotinamide } \\
\hline & $\begin{array}{l}\text { NBT } \\
\triangle \mathrm{OD}\end{array}$ & $\begin{array}{c}\text { Bactericidal } \\
\text { OD20/ } \\
\text { OD140 }\end{array}$ & $\begin{array}{c}\text { Dose } \\
\text { (mg./day) }\end{array}$ & $\begin{array}{c}\text { Days of } \\
\text { Treatment }\end{array}$ & $\begin{array}{l}\text { NBT } \\
\triangle \mathrm{OD}\end{array}$ & $\begin{array}{l}\text { Bactericidal } \\
\text { OD20/ } \\
\text { OD140 }\end{array}$ & $\begin{array}{c}\text { Dose } \\
\text { (mg./day) }\end{array}$ & $\begin{array}{c}\text { Days of } \\
\text { Treatment }\end{array}$ & $\begin{array}{l}\text { NBT } \\
\triangle \mathrm{OD}\end{array}$ & $\begin{array}{c}\text { Bactericidal } \\
\text { OD20/ } \\
\text { OD140 }\end{array}$ \\
\hline $\begin{array}{l}1 \\
2 \\
3 \\
6\end{array}$ & $\begin{array}{l}0.04 \\
0.01 \\
0.05 \\
0.015\end{array}$ & $\begin{array}{l}0.88 \\
0.50 \\
0.94 \\
0.81\end{array}$ & $\begin{array}{l}20 \\
30 \\
20 \\
20\end{array}$ & $\begin{array}{l}28 \\
42 \\
24 \\
32\end{array}$ & $\begin{array}{l}-\overline{0.00} \\
0.03 \\
0.00\end{array}$ & $\begin{array}{l}0 \cdot 92 \\
0 \cdot 92 \\
1 \cdot 07 \\
1 \cdot 02\end{array}$ & 50 & 26 & 0.01 & 0.96 \\
\hline
\end{tabular}

chromatogram of a one-urine specimen from Case 1 showed qualitatively normal amounts of HIAA.

Though the spontaneous excretion of raised amounts of tryptophan metabolites was not found in all the children with chronic granulomatous disease, one child, who excreted normal amounts under basal conditions, was found to metabolize the tryptophan load abnormally.

Abnormalities of tryptophan metabolism, so severe that there is abnormal excretion of these tryptophan metabolites on a normal diet, are relatively rare, and tryptophan loading is usually needed to show the abnormality (Musajo and Benassi, 1964), so our data are not inconsistent with the possibility that this abnormality is general in chronic granulomatous disease.

The abnormality is also unusual because of the predominance of $\mathrm{HKy}$ in the urine of these children. Fig. 2 is an outline of the metabolism of tryptophan. Disturbances might occur as a result of deficiency of the various enzymes either individually, as innate defects, or collectively, as a result of gross liver damage, or the inactivity of co-enzymes of which pyridoxine is of particular importance.

The activity of the kynurenine pathway is influenced by non-specific factors, mediated by the suprarenal, producing changes in the tryptophan pyrollase activity in the liver (Altman and Greengard, 1966). This may result in an excess of excretion of metabolites of the kynurenine pathway, of which $\mathrm{Ky}$ predominates. This is probably the mechanism for the abnormal excretion of these substances in various myeloproliferative disorders (Musajo and Benassi, 1964), in viral hepatitis (Quagliariello et al., 1962), and in a syndrome of mental retardation and epilepsy (Heeley, Piesowicz, and McCubbing, 1968). This mechanism of disturbance of function is also characterized by a fall in $\mathrm{Ky}$ and $\mathrm{HKy}$ excretion on administration of pyridoxine, which is associated with an increase of HAA excretion to greater than normal levels (Musajo and Benassi, 1964; Heeley et al., 1968).

Abnormality of this pathway associated with a predominant excretion of $\mathrm{HKy}$ is related to a deficiency of kynureninase (which metabolizes HKy), or its coenzyme, pyridoxal phosphate. A

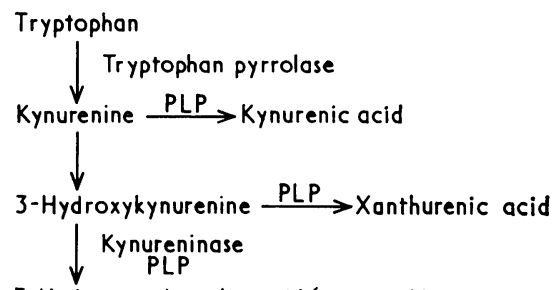

3-Hydroxyanthranilic ocid $\rightarrow \rightarrow$ Nicotinic acid derivatives

Fig. 2.-The metabolism of tryptophan. Enzymic reactions in which pyridoxal phosphate (PLP) acts as coenzyme are indicated. 
patient, who probably produced a functionally defective apoenzyme, had an abnormal excretion of these substances, with $\mathrm{HKy}$ predominating which was not affected by pyridoxine (Komrower et al., 1964). It is worth noting that the amount of hydroxykynurenine excreted by some of our patients was comparable with this patient with an assumed innate enzyme deficiency-indeed one excreted more on tryptophan loading. Deficiency of pyridoxine either in experimental deprivation (Miller and Linkswiler, 1967) or in experimental or therapeutic administration of the pyridoxine antagonist deoxypyridoxine (Price, Brown, and Larson, 1957) produces a similar abnormal excretion, with HKy predominant, which responds to pyridoxine treatment.

The excretion of indole-3-acetic acid, which is produced predominantly by the action of an enzyme found in liver and kidney, tryptophan transaminase (Weissbach et al., 1959), was found to be within normal limits after the administration of a tryptophan load to Case 1. Though several of the children had liver lesions kynureninase deficiency of such severity due to diffuse liver damage would almost certainly be associated with abnormalities in other liver enzyme systems.

Our finding in chronic granulomatous disease of an abnormal excretion of both $\mathrm{Ky}$ and $\mathrm{HKy}$, with the latter predominating, which was reversed by pyridoxine, most resembles pyridoxine deficiency. These children ate a normal diet, so this could only arise as a result of abnormal utilization of, or insensitivity to, pyridoxine. The possibility that micro-organisms use up the available pyridoxine must be considered; three children with chronic infection of other cause, whom we studied, did not show a similar defect, but this cannot be regarded as fully excluding this possibility. The children had all received large amounts of antibiotics at some stage of their illness, though not all were receiving antibiotics at the time of study, and they were receiving no other drug in common. The control children with chronic infections had also received large quantities of antibiotics. We do not think that our findings can be explained by the effect of such treatment, though the possibility cannot be excluded on our present data.

It is likely that there is a continual proliferation of polymorphs in these children, so the possibility arises that the abnormality might be comparable with that occurring in myeloproliferative disorders, but they do not have the specific excess of HKy. The response to pyridoxine appears to exclude a deficiency or abnormality of kynureninase as an explanation, so an abnormality of pyridoxine metabolism is the most likely explanation, and we are making further studies of this in these patients.

The kynurenine pathway may contribute to nicotinic acid production, and nicotinic acid is a constituent of DPNH, the substrate of an enzyme thought possibly to be the one responsible for the defect of polymorph function (Baehner and Karnovsky, 1968). Since enzyme concentration may be related to substrate concentration, we investigated the effect of both pyridoxine, and nicotinamide treatment on leucocyte function. We noticed no such effect in the period of study, but it is not yet possible to conclude that the correction of the metabolic defect is not beneficial.

We are grateful to Dr. Barbara E. Clayton for her advice and encouragement throughout this investigation, and to Dr. P. R. Evans and Dr. G. H. Newns under whose care the children were during the investigation. The financial support of the Nuffield Foundation and the Medical Research Council is gratefully acknowledged.

\section{REFERENCES}

Altman, K., and Greengard, O. (1966). Correlation of kynurenine excretion with liver tryptophan pyrrolase levels in disease and after hydrocortisone induction. Fournal of Clinical Investigation, 45, 1527.

Baehner, R. L., and Karnovsky, M. L. (1968). Deficiency of reduced nicotinamide-adenine dinucleotide oxidase in chronic granulomatous disease. Science, 162, 1277.

, and Nathan, D. G. (1968). Quantitative nitroblue tetrazolium test in chronic granulomatous disease. New England fournal of Medicine, 278, 971.

Berendes, H., Bridges, R. A., and Good, R. A. (1957). A fatal granulomatous disease of childhood: the clinical study of a new syndrome. Minnesota Medicine, 40, 309.

Chandra, R. K., Cope, W. C., and Soothill, J. F. (1970). To be published.

Denckla, W. D., and Dewey, H. K. (1967). The determination of tryptophan in plasma, liver and urine. Fournal of Laboratory and Clinical Medicine, 69, 160.

Heeley, A. F. (1965). The effect of pyridoxine on tryptophan metabolism in phenylketonuria. Clinical Science, 29, 465.

(1966). Tryptophan metabolism in children, with particular reference to psychosis. Ph.D. Thesis. University of London.

, Piesowicz, A. T., and McCubbing, D. G. (1968). The biochemical and clinical effect of pyridoxine in children with brain disorders. Clinical Science, 35, 381.

Jepson, J. B. (1969). Indoles and related Ehrlich reactions. In Chromatographic and Electrophoretic Techniques, 3rd ed., Vol. 1, p. 243. Ed. by I. Smith. Heinemann, London.

Komrower, G. M., Wilson, V., Clamp, J. R., and Westall, R. G. (1964). Hydroxykynureninuria. A case of abnormal tryptophan metabolism probably due to a deficiency of kynureninase. Archives of Disease in Childhood, 39, 250.

Michael, A. F., Drummond, K. N., Doeden, D., Anderson, J. A. and Good, R. A. (1964). Tryptophan metabolism in man. Fournal of Clinical Investigation, 43, 1730.

Miller, L. T., and Linkswiler, H. (1967). Effect of protein intake on the development of abnormal tryptophan metabolism by men during vitamin $\mathbf{B}_{6}$ depletion. Fournal of Nutrition, 93, 53.

Musajo, L., and Benassi, C. A. (1964). Aspects of disorders of the kynurenine pathway of tryptophan metabolism in man. Advances in Clinical Chemistry, 7, 63.

Price, J. M., Brown, R. R., and Larson, F. C. (1957). Quantitative studies on human urinary metabolites of tryptophan as affected by isoniazid and desoxypyridoxine. Fournal of Clinical Investigation, 36, 1600.

Quagliariello, E., Tancredi, F., Sascone, C., and Piazza, M. (1962). Interrelation between tryptophan and nicotinic acid in human viral hepatitis. Nature, 194, 976. 
Quie, P. G., White, J. G., Holmes, B., and Good, R. A. (1967). In vitro bactericidal capacity of human polymorphonuclear leukocytes: diminished activity in chronic granulomatous disease of childhood. Fournal of Clinical Investigation, 46, 668.

Thompson, E. N., and Soothill, J. F. (1970). Chronic granulomatous disease: quantitative clinicopathological relationships. Archives of Disease in Childhood, 45, 24.

Weissbach, H., King, W., Sjoerdsma, A., and Udenfriend, S. (1959). Formation of indole-3-acetic acid and tryptamine in animals. fournal of Biological Chemistry, 234, 81.
Windhorst, D. B., Holmes, B., and Good, R. A. (1967). A newly defined X-linked trait in man with demonstration of the Lyon effect in carrier females. Lancet, 1, 737.

Yarbro, M. T., and Anderson, J. A. (1966). L-tryptophan met bolism in phenylketonuria. Fournal of Pediatrics, 68, 895.

Correspondence to Professor J. F. Soothill, Department of Immunology, Institute of Child Health, 30 Guilford Street, London W.C.1. 